\title{
Simultaneous Measurement of Pressure in the Calyces During RIRS in a Human Cadaver Model
}

\author{
Insan Kadavra Böbrek Modelinde RIRS SIrasında Kalikslerin Eş Zamanlı Basınç Ölçümü
}

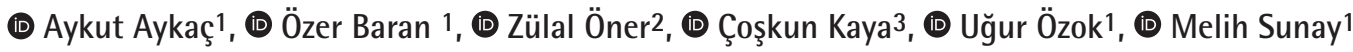 \\ ${ }^{1}$ Karabük University Faculty of Medicine, Department of Urology, Karabük, Turkiye \\ ${ }^{2}$ Karabük University Faculty of Medicine, Department of Anatomy, Karabük, Turkiye \\ ${ }^{3}$ Eskişehir City Hospital, Clinic of Urology, Eskişehir, Turkiye
}

\section{What's known on the subject? and What does the study add?}

In previous studies in literature, intrarenal pressure measurement has been made at the renal pelvis level. To the best of our knowledge, there has been no study in the English literature that has shown whether the renal pelvis pressure is reflected at the same level in the renal calyces or that has evaluated the effect of the pressure in the examined calyx on the other calyces.

\begin{abstract}
Objective: The aim of this study was to evaluate calyceal pressure caused by irrigation of the upper, mid and lower calyces in a cadaver kidney model and to examine the interactions.

Materials and Methods: The kidney was dissected together with the ureter from a human cadaver from a 75-year-old without a history of renal disease. Catheters were placed in the bases of the calyces to perform pressure measurements. After recording baseline pressures while the flexible ureteroscope working channel was empty during irrigation, pressures were then measured by administering fluid with a hand pump, 5 cc and 50 cc syringe. Then, $272 \mu$ and $350 \mu$ laser probes were placed in the flexible ureteroscope and, after recording the baseline calyceal pressures, the measurements were repeated 3 times during hand pump irrigation.

Results: Lowest calyceal pressures were measured when a $300 \mu$ laser probe in the working channel of the flexible ureteroscope was placed in the upper calyx during irrigation at $60 \mathrm{~cm} \mathrm{H2O}$. Independent of the location of the flexible ureteroscope, the pressure in all the calyces was observed to be $\geq 50 \mathrm{mmHg}$ during all types of fluid irrigation. All the calyceal pressures were observed to be affected by each other. The pressure within the calyx where the flexible ureteroscope was located was statistically significantly higher than in the other calyces $(p<0.001)$.

Conclusion: Application of additional fluid irrigation during flexible ureteroscopy causes a serious increase in intrarenal pressure. If fluid irrigation is to be applied, it should be done using a very small amount of fluid and for a very short duration.
\end{abstract}

Keywords: Intrarenal pressure, Retrograde intrarenal surgery, RIRS, Calyx pressure

$0 \ddot{z}$

Amaç: Çalışmamızda kadavra böbrek modelinde üst, orta ve alt kalikste farklı irrigasyon uygulamaları ile oluşan kaliksiyel basınçları ve birbirleri ile etkileşimlerini değerlendirmeyi amaçladık.

Gereç ve Yöntem: Yetmiş beş yaşında bilinen böbrek hastalığı öyküsü olmayan insan kadavra böbreği üreteri ile birlikte diseke edildi. Kateter uçları kaliks tabanına gelecek şekilde yerleştirildi. Flexible ureteroskop çalışma kanalı boş iken bazal basınçlar kayıt edildikten sonra pump, 5 cc ve 50 cc enjektör ile sıvı verilerek basınçlar ölçüldü. Daha sonra flexible ureteroskopun içinden 272 ve $350 \mu$ lazer probu yerleştirilerek bazal ve pump yapılarak 3 kez aynı işlemler tekrarlandı.

Bulgular: Tüm kalikslerin basınçları en düşük $60 \mathrm{~cm}$ H20 irrigasyon sırasında flexible urs üst kalikste çalışma kanalı $300 \mu$ lazer var iken ölçüldü. Flexible URS Iokalizasyonundan bağımsız olarak uygulanan her türlü sıvı irrigasyonunda tüm kalikslerde basıncın $50 \mathrm{mmHg}$ ve üzerine çıktığı izlendi.

Correspondence: Aykut Aykaç MD, Karabük University Faculty of Madicine, Department of Urology, Karabük, Turkiye Phone: +90 50579929 95 E-mail: aykutdr@gmail.com ORCID-ID: orcid.org/0000-0001-7078-0135

Received: 19.11.2018 Accepted: 27.02.2019

Cite this article as: Aykaç A, Baran Ö, Öner Z, Kaya C, Özok U, Sunay M. Simultaneous Measurement of Pressure in the Calyces During RIRS in a Human Cadaver Model. J Urol Surg 2019;6(3):213-217.

๑Copyright 2019 by the Association of Urological Surgery / Journal of Urological Surgery published by Galenos Publishing House. 
Tüm kaliks basınçlarının birbirinden etkilendiği gözlendi. Flexible URS'nin bulunduğu kaliks içinde basınçlar diğerlerinden daha yüksek ölçüldü ve bu istatistiksel olarak anlamlı idi $(p<0,001)$.

Sonuç: Flexible ureteroskopi sırasında ek sıvı irrigasyonu yapılması böbrek içi basınçlarında ciddi artışa neden olmaktadır. Sıvı irrigasyonu yapılacaksa çok kısa süreli ve mümküm olduğunca az uygulanmalıdır.

Anahtar Kelimeler: İntrarenal basınç, Retrograd intrarenal cerrahi, RIRC, Kaliks basınç

\section{Introduction}

Technological developments in flexible ureteroscopy (fURS) aim to increase image quality $(1,2,3)$. By increasing pixel resolution of digital ureteroscopes, it is aimed to obtain better vision. However, even though developments in optical sources continue, another factor defining vision quality during ureteroscopy is fluid irrigation. Especially during stone breakage with laser, the stone dust cloud disrupts the view and it is attempted to correct this with fluid irrigation. Irrigation may lead to an increase in intrarenal pressure. The use of a ureteral access sheath is recommended to decrease elevated intrarenal pressure (4). There are reports showing that even if a ureteral access sheath is used, intrarenal pressures reach a critical level (5). In previous studies in the literature, intrarenal pressure measurement has been made at the renal pelvis $(6,7)$. To the best of our knowledge, there has been no study in the English literature investigating whether the renal pelvis pressure was reflected at the same level in the renal calyces or evaluating the effect of the pressure in the examined calyx on the other calyces.

The aim of this study was to evaluate calyceal pressure caused by irrigation of the upper, mid and lower calyces in a cadaver kidney model and to examine the interactions.

\section{Materials and Methods}

The kidney was dissected together with the ureter from a human cadaver of a 75-year-old without a history of renal disease. An Elite Flex (Istem Medikal, Ankara, Turkiye) 10/12 Fr, $35 \mathrm{~cm}$ ureteral access sheath was placed in the ureteral lumen below the ureteropelvic junction and the sheath was fixed to the lumen with a 2.0 vicryl suture. The calyx structures were identified with retrograde pyelography. Under fluoroscopic guidance, catheters were placed in the upper, mid and lower calyces for pressure measurements. The pressure values were recorded by attaching the catheters to a Dräger Fabius plus XL (Dräger Medical $\mathrm{GmbH}$, Germany) arterial pressure monitor (Figure 1). A Storz Flex- $x^{2 s}$ (Tuttlingen/Germany) flexible ureteroscope was rotated to the pelvis, the upper calyx, the mid calyx and the lower calyx. The catheters were observed to be placed within the calyx structures. The ends of the catheters were placed to be at the base of the calyx.

The calyceal pressure where the measurement was made and the simultaneous pressures formed in the other calyces were recorded during the measurement process. After recording the baseline pressures while the flexible ureteroscope working channel was empty during irrigation at $60 \mathrm{~cm} \mathrm{H}_{2} \mathrm{O}$ level, pressures were then measured by administering fluid with a hand pump, and $5 \mathrm{cc}$ and $50 \mathrm{cc}$ syringe. Each procedure was repeated 3 times; irrigation was applied for about $3 \mathrm{sec}$ and repeated when the pressure levels reached the baseline levels. Maximum pressure values were noted and average pressure values were calculated. Then, 272 and $350 \mu$ laser probes were placed inside the working channel of the flexible ureteroscope and after recording the baseline calyceal pressures, the measurements were repeated 3 times during hand pump irrigation.

\section{Statistical Analyses}

Statistical analyses of the study data were made using IBM SPSS Statistics 21.0 software (IBM SPSS Statistics for Windows, version 21.0 (2012 release) Armonk, NY, USA). Conformity of the data to normal distribution was evaluated using the Shapiro-Wilks test. In the comparison of values at different measurement times, the Wilcoxon test was used when there were 2 groups and the Friedman test when there were 3 or more groups. For repeated measurements, the two-way repeated measures ANOVA (one factor repetition) was applied. Pearson's chi-square test was used to analyse the cross-tables formed. A p value of less than 0.05 was considered statistically significant.

\section{Results}

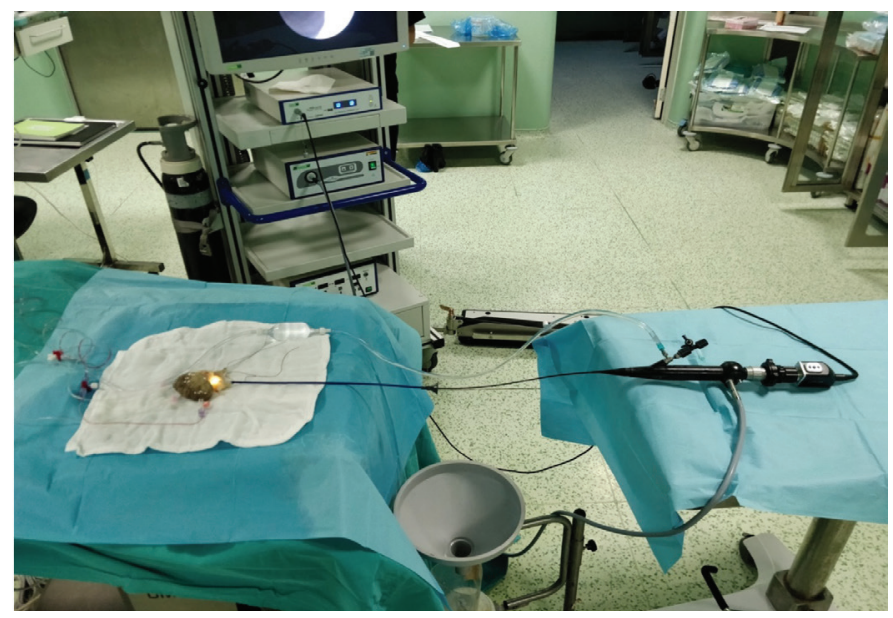

Figure 1. Simultaneous measurement of pressure of the calyces on cadaver kidney model 
In this study, the lowest pressures in all the calyces were measured when a $300 \mu$ laser probe in the working channel of the flexible ureteroscope was placed in the upper calyx during irrigation at $60 \mathrm{~cm} \mathrm{H}_{2} 0$. The pressures were measured to be $<10 \mathrm{mmHg}$. The highest calyceal pressure values were measured when the pump was applied in the middle calyx while the working canal

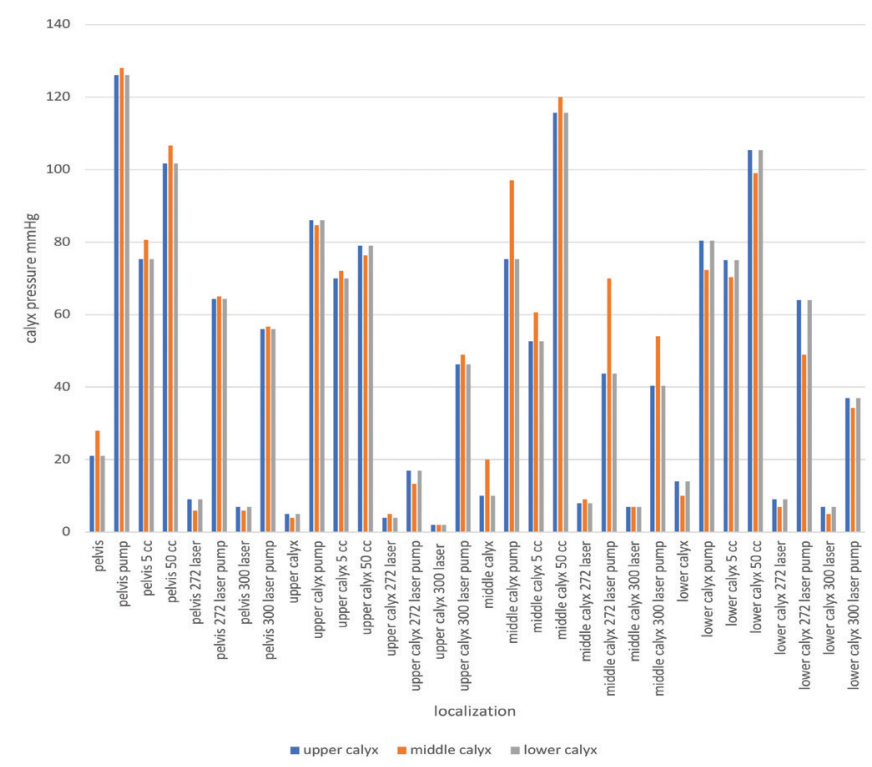

Figure 2. Average pressure of calices

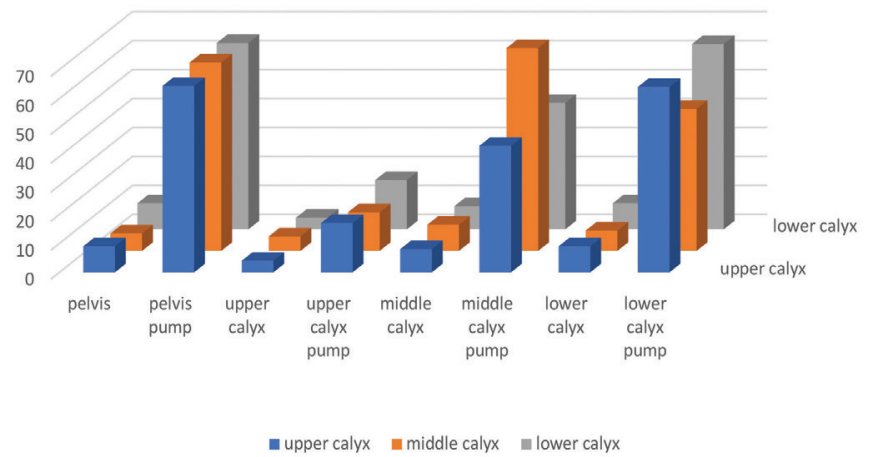

Figure 3. Working chanel with $272 \mu$ laser

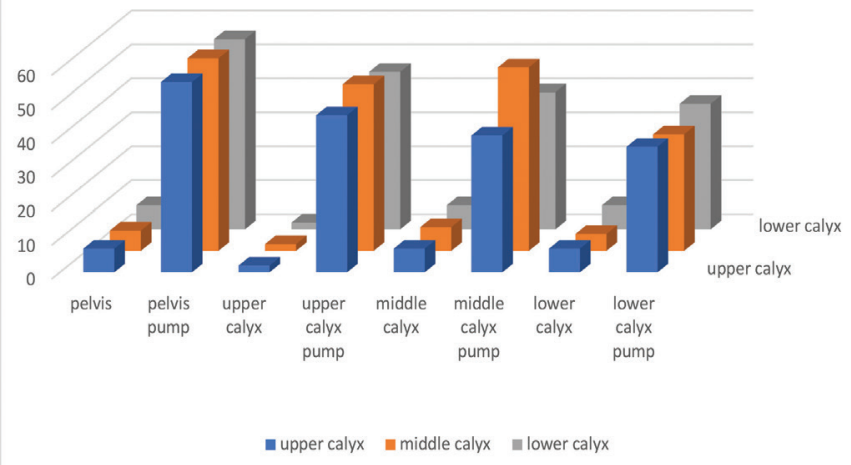

Figure 4. Working chanel with $300 \mu$ laser was empty and the flexible ureteroscope was in the pelvis. The pressures were $>100 \mathrm{mmHg}$ (Figure 2).

Independent of the flexible ureteroscope location, the pressure in all the calyces was observed to be $\geq 50 \mathrm{mmHg}$ during all types of fluid irrigation $(p=0.610)$. With $5 c c$ irrigation, there was a 12.98 -fold increase in the risk of pressures $>50 \mathrm{mmHg}$ in all the calyx groups even with a laser probe in the working canal, compared to the baseline pressure measurements $(p<0.001)$. The greatest difference in the measurements made with $5 \mathrm{cc}$ irrigation and when the working canal was empty was observed to be in the upper calyx group $(p<0.001)$.

Using a hand pump together with $272 \mu$ laser created a 4.27fold increase in the risk of developing pressures more than 50 $\mathrm{mmHg}$ compared to baseline value with $272 \mu$ laser. A difference was observed in all the calyx groups during the procedure with the greatest difference when the flexible ureteroscope was in the pelvis $(p<0.001)$ (Figure 3$)$.

Using a hand pump together with $300 \mu$ laser created a 2.89fold increase in the risk of developing pressures $>50 \mathrm{mmHg}$ compared to the baseline value $(p<0.001)$. A difference was observed in all the calyx groups during the procedure with the greatest difference when the flexible ureteroscope was in the ureter. The lowest difference was observed when the flexible ureteroscope was in the lower calyx $(p<0.001)$ (Figure 4).

All the calyceal pressures were observed to be affected by each other. The pressure within the calyx where the flexible ureteroscope was located was found to be statistically significantly higher than in the other calyces $(p<0.001)$. When the flexible ureteroscope was located in the pelvis and the upper and mid calyx, the highest pressures were reached with pump applied while the working canal was empty, and the highest pressure was obtained with $50 \mathrm{cc}$ irrigation when the flexible ureteroscope was in the lower calyx $(p<0.001)$.

\section{Discussion}

Endoscopic imaging and treatment of the upper urinary system is greatly facilitated with fURS. It is the first-line recommended method in the guidelines for the treatment of upper urinary system stones in particular (8). However, there are still some problems associated with the currently increasing widespread use of this method. In this respect, there are developments in finer instruments, digital camera systems to increase image quality, the use of different laser probes and endoscopic basket catheters specific for this procedure. While developments are increasing success of the procedure, there are also ongoing studies investigating the effects on kidney.

Fluid irrigation applied to increase the vision quality causes an increase in intrarenal pressure. Under physiological conditions, 
the intrarenal pelvic pressure has been reported to vary between $0 \mathrm{mmHg}$ and $15 \mathrm{mmHg}$ (5). When a ureteral access sheath with a semi-rigid or flexible ureteroscope, intrarenal pressure has been reported to increase to $100-300 \mathrm{mmHg}$ with irrigation $(5,9)$. Auge et al. (10) evaluated intrarenal pressure with measurements made via a nephrostomy catheter in different ureter segments without the use of a ureteral access sheath and determined a decrease of 57\%-75\% in intrarenal pressure with the use of a ureteral access sheath. There is a greater reduction in intrarenal pressure with larger sized ureteral access sheaths. However, even though the use of a large ureteral access sheath may lead to lower intrarenal pressure, there is an increased risk of ureteral damage (11). Al-Qahtani et al. (12) reported the ideal access sheath diameter to be 10/12 Fr. For this reason, we used 10/12 Fr ureteral access sheath in the study.

As it is known from animal and human studies, with an increase of intrarenal pressure to $20-30 \mathrm{mmHg}$, pyelo-tubular backflow develops and blood circulation of the kidney decreases $(13,14)$. When intrarenal pressure increases to $30-50 \mathrm{mmHg}$, the pyelovenous backflow becomes more evident and an increase in both pyelosinus and pyelolymphatic pressures results in forniceal rupture $(14,15)$. It has been reported that a pelvic pressure of $\geq 30 \mathrm{mmHg}$ during rigid nephrolithotomy was associated with higher pain score and longer hospital stay (16). Therefore, pyelo-tubular and even pyelovenous and pyelolymphatic backflow almost always occurs with the intrarenal pressure seen during routine fURS, and this can potentially cause infectious and hemorrhagic complications in addition to impaired renal function (5). In the current study, even in the presence of a laser probe in the working canal, pressures were observed to be $\geq 50$ $\mathrm{mmHg}$ in all types of additional fluid irrigation.

In association with increasing intrarenal pressure, fluid passes into the bloodstream. Guzelburc et al. (17) reported that fluid absorption ranged between $20 \mathrm{~mL}$ and $573 \mathrm{~mL}$ in patients undergoing RIRS. An increased fluid volume can create problems in cardiac patients and those with renal failure. In the current study, there was fluid extravasation from the kidney parenchyma during the procedure. According to the results of this study, administration of diuretics may be recommended in the presence of contraindications found during fURS to avoid fluid overload and to reduce the risk of parenchymal fluid transfer. In the current study, it was observed that the calyceal pressures were increased during fluid administration with flexible ureteroscope while the working canal was empty. It is recommended to avoid fluid irrigation while the working canal is empty during fURS. Long duration of irrigation can increase the risk of the development of complications. Intrarenal pressure was observed to significantly increase even during irrigation made using a 5 cc syringe. All the calyceal pressures were observed to be affected by each other. It is possible to reach high pressures even with a small amount of fluid due to low renal pelvic capacity. Different results can be obtained in different pelvic volumes. The lowest pressures in the calyces were obtained with a $300 \mu$ laser probe in the $3.6 \mathrm{Fr}$ working channel of the fURS. As the diameter of the laser fiber increases, the amount of fluid passing through the working channel decreases and the intrarenal pressure remains low. However, in our study additional 5 cc fluid applications were sufficient to increase intrarenal pressure. When a manual pump is used in clinical practice, the applied force will be different every time, resulting in different amounts of fluid. Waiting for intra-renal pressure to decrease after each additional fluid applied for dust removal may be a solution to avoid possible complications.

Different approaches for reducing intrarenal pressure can be found in the literature. In a study performed in a porcine model by Zhu et al. (18), success was reported in maintaining low renal pelvic pressure with flexible ureteroscope at different flow rates with the use of a smart pressure control device. In the same study, following perfusion applied while the flexible ureteroscope was in the upper calyx, the upper calyceal pressure was temporarily higher than the pelvic outlet pressure. Huang et al. (19) successfully treated patients with a solitary kidney and upper urinary tract calculus by protecting low renal pressure using a device with a suction system. With endoluminal application of $0.1 \mu \mathrm{g} / \mathrm{mL}$ isoproterenol to reduce intrarenal pressure, Jung et al. (9) reported that intrarenal pressures were reduced without any cardiac side-effects.

\section{Study Limitations}

There are some limitations in the current study. The measurements were made on a single cadaver kidney. The effect on pressures in different calyx structures and length of the calyx neck could not be evaluated. As this was a cadaver kidney, the tissue elasticity and resistance were different from that of a normal kidney. Therefore, the pressures in this study may be different than in those in routine procedures. Fluid extravasation during the procedure caused a decrease in the measured calyceal pressures, and the amount of fluid returning from the access sheath could not be evaluated because of the extravasation. Fixing the sheath to the ureteropelvic junction with suturing may also affect the pressures. In addition, the effect of different diameters of ureteral access sheaths on calyceal pressures could not be evaluated.

\section{Conclusion}

Application of additional fluid irrigation during fURS causes a serious increase in intrarenal pressure. Even in irrigation made using a 5 cc syringe, intrarenal pressure was found to be significantly increased. If fluid irrigation is to be applied, it 
should be done using a very small amount of fluid and for a very short duration. During fURS, diuretics can be useful for avoiding fluid overload. Although the upper calyx is the most affected, there the pressure may increase in all calyces.

\section{Ethics}

Ethics Committee Approval: There is no need ethics committee approve for cadaveric study.

Informed Consent: You can't get a consent if you can do cadaver work.

Peer-review: Externally peer-reviewed.

\section{Authorship Contributions}

Concept: A.A., Design: A.A., Data Collection and/or Processing: Z.Ö., Ö.B., C.K., Analysis and/or Interpretation: Ö.B., C.K., Literature Research: A.A., Ö.B., Writing: A.A. Content and Supervision: U.Ö., M.S.

Conflict of Interest: No conflict of interest was declared by the authors.

Financial Disclosure: None.

\section{References}

1. Talso $M$, Proietti $S$, Emiliani $E$, Gallioli $A$, Dragos $L$, Orosa $A$, Servian $P$, Barreiro A, Giusti G, Montanari E, Somani B, Traxer 0. Comparison of Flexible Ureterorenoscope Quality of Vision: An In Vitro Study. J Endourol 2018;32:523-528.

2. Emiliani $E_{1}$ Talso $M$, Baghdadi $M$, Barreiro $A$, Orosa $A$, Serviàn $P$, Gavrilov $P$, Proietti $S$, Traxer 0. Evaluation of the Spies (TM) modalities image quality. Int Braz J Urol 2017;43:476-480

3. Proietti S, Dragos L, Molina W, Doizi S, Giusti G, Traxer O. Comparison of New Single-Use Digital Flexible Ureteroscope Versus Nondisposable Fiber Optic and Digital Ureteroscope in a Cadaveric Model. J Endourol 2016;30:655659.

4. Ng YH, Somani BK, Dennison A, Kata SG, Nabi G, Brown S. Irrigant flow and intrarenal pressure during flexible ureteroscopy: the effect of different access sheaths, working channel instruments, and hydrostatic pressure. J Endourol 2010;24:1915-1920.

5. Jung $H$, Osther PJ. Intraluminal pressure profiles during flexible ureterorenoscopy. Springerplus 2015;4:373.

6. Rehman J, Monga M, Landman J, Lee DI, Felfela T, Conradie MC, Srinivas R, Sundaram CP, Clayman RV. Characterization of intrapelvic pressure during ureteropyeloscopy with ureteral access sheaths. Urology 2003;61:713-718.
7. Wright A, Williams K, Somani B, Rukin N. Intrarenal pressure and irrigation flow with commonly used ureteric access sheaths and instruments. Cent European J Urol 2015;68:434-438.

8. Türk C, Petrik A, Sarica K, Seitz C, Skolarikos A, Straub M, Knoll T. EAU Guidelines on Interventional Treatment for Urolithiasis. Eur Urol 2016;69:475-482.

9. Jung H, Norby B, Frimodt-Moller PC, Osther PJ. Endoluminal isoproterenol irrigation decreases renal pelvic pressure during flexible ureterorenoscopy: a clinical randomized, controlled study. Eur Urol 2008;54:1404-1413.

10. Auge BK, Pietrow PK, Lallas CD, Raj GV, Santa-Cruz RW, Preminger GM. Ureteral access sheath provides protection against elevated renal pressures during routine flexible ureteroscopic stone manipulation. J Endourol 2004;18:33-36

11. Sener TE, Cloutier J, Villa L, Marson F, Buttice S, Doizi S, Traxer O. Can We Provide Low Intrarenal Pressures with Good Irrigation Flow by Decreasing the Size of Ureteral Access Sheaths? J Endourol 2016:30:49-55.

12. Al-Qahtani SM, Letendre J, Thomas A, Natalin R, Saussez T, Traxer O. Which ureteral access sheath is compatible with your flexible ureteroscope? J Endourol 2014;28:286-290.

13. Thomsen HS, Dorph S, Larsen S, Talner LB. Intrarenal backflow and rena perfusion during increased intrapelvic pressure in excised porcine kidneys. Acta Radiol Diagn (Stockh) 1983;24:327-336.

14. Thomsen HS, Larsen S, Talner LB. Pyelorenal backflow during retrograde pyelography in normal and ischemic porcine kidneys. A radiologic and pathoanatomic study. Eur Urol 1982;8:291-297.

15. Durhan G, Ayyildiz VA, Ciftci $\Pi$, Akata D, Ozmen MN. Pyelolymphatic backflow demonstrated by an abdominal CT: A case report. Pol J Radiol 2014;79:6-8

16. Alsyouf $M$, Abourbih $S$, West $B$, Hodgson H, Baldwin DD. Elevated Renal Pelvic Pressures during Percutaneous Nephrolithotomy Risk Higher Postoperative Pain and Longer Hospital Stay. J Urol 2018;199:193-199.

17. Guzelburc V, Balasar M, Colakogullari M, Guven S, Kandemir A, Ozturk A, Karaaslan P, Erkurt B, Albayrak S. Comparison of absorbed irrigation fluid volumes during retrograde intrarenal surgery and percutaneous nephrolithotomy for the treatment of kidney stones larger than $2 \mathrm{~cm}$. Springerplus 2016;5:1707.

18. Zhu X, Song L, Xie D, Peng Z, Guo S, Deng X, Liu S, Fan D, Huang J, Liu T, Du C, Zhu L, Yang Z, Peng G, Hu M, Yao L, Zeng M, Zhong J, Qing W, Ye Z. Animal Experimental Study to Test Application of Intelligent Pressure Control Device in Monitoring and Control of Renal Pelvic Pressure During Flexible Ureteroscopy. Urology 2016;91:242

19. Huang J, Xie D, Xiong R, Deng X, Huang C, Fan D, Peng Z, Qin W, Zeng M, Song L. The Application of Suctioning Flexible Ureteroscopy With Intelligent Pressure Control in Treating Upper Urinary Tract Calculi on Patients With a Solitary Kidney. Urology 2018;111:44-47. 